* Mestre pela Faculdade de Direito da Universidade de Coimbra. Doutorando na mesma Instituição. Pesquisador junto ao Instituto de Direito Penal da Universidade de Bonn. Bolsista da Fundação para a Ciência e a Tecnologia de Portugal. Email: brunodeoliveiramoura @ yahoo.com.br

\section{A responsabilidade civil extracontratual do Estado e demais entidades públicas no exercício da função administrativa: uma breve análise do regime português}

\author{
Non-CONTRaCtUal LIABILITY OF THE STATE AND \\ OTHER PUBLIC ENTITIES IN THE EXERCISE OF THE \\ ADMINISTRATIVE FUNCTION: A BRIEF ANALYSIS OF \\ THE PORTUGUESE REGIME
}

* Bruno Moura

Resumo: O artigo analisa o modelo português de responsabilidade civil extracontratual do Estado no exercício da função administrativa e chama a atenção para as dificuldades que um esquema puramente consequencialista de distribuição de responsabilidade pode enfrentar segundo a sua própria lógica do custo-benefício.

Palavras-Chave: Administração pública; Responsabilidade civil extracontratual do Estado.

Abstract: The article analyzes the Portuguese model of noncontractual civil liability of the State in the exercise of administrative function and draws attention to the difficulties that a purely consequentialist scheme of distribution of responsibility may face even according to their own cost-benefit logic.

Keywords: Public administration; Non-contractual civil liability of the state. 


\section{INTRODUÇÃO}

Depois de uma série de tentativas legislativas (MEDEIROS, 2005, p. 24-25; MESQUITA, 2009, p. 10-11; MONCADA, 2006, p. 11-12), o novo regime da responsabilidade civil extracontratual do Estado e demais entidades públicas (Lei n ${ }^{\circ}$. 67/2009) veio a lume com o objetivo de melhor atender às exigências axiológico-normativas emanadas do art. $22^{\circ}$ da Constituição da República Portuguesa, o qual consagra a responsabilidade solidária do Estado e demais entidades públicas como um princípio indispensável à concretização do Estado de Direito democrático ${ }^{1}$ (CORREIA, 2011, p. 145-146). Com efeito, o trabalho crítico da dogmática jurídico-constitucional e jurídicoadministrativa acabou revelando a insuficiência ou a inadequação do Direito ordinário até então vigente (Decreto-Lei $n^{\circ}$. 48051/67) em face da Lei Fundamental (CADILHA, 2008, p. 236-237; MESQUITA, 2009; QUADROS, 2009, p. 115).

Atenta à crítica doutrinária e aos esforços de densificação levados o cabo através da jurisprudência, a Lei nº 67/2009 decidiu-se em favor de um considerável "alargamento" (NABAIS, 2009, p. 731) da responsabilidade do Estado. Neste horizonte, além de ampliar o regime da responsabilidade no exercício da função administrativa (v.g., através da flexibilização dos pressupostos da responsabilidade pelo risco) e de não mais circunscrever a figura da indenização pelo sacrifício ao exercício desta função, o novo modelo legal estabelece um regime geral de responsabilidade no exercício da função jurisdicional e cria um inovador regime em matéria de responsabilidade no exercício da função político-legislativa (ANDRADE, 2011a, p. 345 e ss; GOMES, 2008, p. 64; MESQUITA, 2009, p. 16-17).

Deixando de lado, brevitatis causa, a análise global das várias controvérsias sobre o alcance deste modelo (ANDRADE, 2011a, p. 345; GOMES, 2008, p. 25) e das objeções contra ele formuladas (MESQUITA, 2009, p. 13-15; NABAIS, 2009, p. 730), o estudo em tela busca fazer da necessidade uma virtude e centrar sua limitada atenção no aspecto lógicoestrutural do novo regime em matéria de responsabilidade do EstadoAdministração por fatos ilícitos. Neste horizonte teleologicamente recortado,

\footnotetext{
O regime de responsabilidade encontra seu comum fundamento constitucional no princípio do Estado de direito democrático (arts. $2^{\circ}$ e $9^{\circ}$, b da Constituição Portuguesa), do qual se deduz um "direito geral dos cidadãos à reparação dos danos provenientes de acções ou omissões".
} 
o trabalho debruça-se - com a redobrada cautela sempre necessária àqueles que se aventuram a trabalhar em outros domínios - sobre duas questões lógico-analíticas verdadeiramente estruturantes da nova sistemática: a distinção entre atos de gestão pública e atos de gestão privada (item 2) e a configuração do esquema de distribuição de responsabilidades entre os sujeitos discursivamente relevantes (item 3).

\section{A CLIVAGEM FUNDAMENTAL:ATOS DE GESTÃO PÚBLICA VERSUS ATOS DE GESTÃO PRIVADA}

A distinção teórica entre "atos de gestão pública" e "atos de gestão privada" constitui o tradicional ponto de partida de toda a dogmática jurídicoadministrativa da responsabilidade civil extracontratual do Estado e das demais entidades públicas (ANDRADE, 2011b, p. 346; SOUSA; MATOS, 2009, p. 479-480). Com efeito, esta difícil e insegura clivagem conceitual (CORDEIRO, 2010, p. 635 e ss; PINHEIRO, 2002, p. 67-69; SILVA, 2003, p. 61-62; SOUSA; MATOS, 2009, p. 483) foi expressamente assumida como base do regime legal anterior: segundo o art. $1^{\circ}$ do antigo Decreto-Lei $n^{\circ} .48051 / 67$, o modelo normativo ali estabelecido regulava "a responsabilidade civil extracontratual do Estado e demais pessoas colectivas públicas no domínio dos actos de gestão pública".

Durante muito tempo esta divisão consoante a natureza do ato de gestão praticado assumiu consequências não só substantivas (referidas ao Direito material a ser aplicado), mas também processuais (atinentes à jurisdição competente). No plano substantivo, a responsabilidade administrativa em virtude de ato de gestão pública era regida através do Direito administrativo e a responsabilidade administrativa em razão de ato de gestão privada sujeitavase ao regime de Direito privado. Na dimensão processual, a responsabilidade administrativa em virtude de ato de gestão pública era apreciada diante dos tribunais administrativos e a responsabilidade administrativa em razão de ato de gestão privada era avaliada perante os tribunais comuns (judiciais) (CORDEIRO, 2010, p. 632-633; CORTEZ, 2002, p. 257-258; SOUSA; MATOS, 2009, p. 483).

No entanto, o Estatuto dos Tribunais Administrativos e Fiscais (LISBOA, 2002) eliminou a consequência processual acima indicada, ao estabelecer a unidade de jurisdição relativamente às ações de responsabilidade civil 
extracontratual do Estado e das demais entidades públicas² (CADILHA, 2008, p. 235-236; PINHEIRO, 2002, p. 67). Com efeito, ao deixar de vincular a determinação do foro competente à distinção entre atos de gestão pública e atos de gestão privada (art. $4^{\circ}, \mathrm{n}^{\mathrm{o}} .1^{\circ}, g$ e $\left.h\right)^{3}$ (AMARAL, 2002, p. 44), o legislador remete aos tribunais administrativos o processamento e julgamento de toda e qualquer ação de responsabilidade civil a envolver o Estado, independentemente da natureza do ato de gestão gerador da obrigação de indenizar (ANDRADE, 2011a, p. 103-104, ANDRADE, 2008, p. 361; MONCADA, 2006, p. 20-21; SILVA, 2003, p. 60-64; SOUSA; MATOS, 2009, p. 483). Neste horizonte normativo, resta saber se subsiste a consequência substancial da distinção.

A Lei $n^{\circ} .67 / 2007$ em momento algum recorre expressamente à figura do "ato de gestão pública". Ao invés disso, prefere trabalhar - na esteira do "exercício das suas funções" mencionado nos arts. $22^{\circ}$ e $271^{\circ}$ da Constituição da República Portuguesa - nominalmente com o conceito de "função administrativa". Com efeito, os arts. $7^{\circ}, \mathrm{n}^{\circ} .1$ e $8^{\circ}, \mathrm{n}^{\circ} .2$ do Regime referem-se aos danos causados "no exercício da função administrativa e por causa deste exercício" e o art. $1^{\circ}, \mathrm{n}^{\circ} .2$ concebe o "exercício da função administrativa" como "as acções e omissões adoptadas no exercício de prerrogativas de poder público ou reguladas por disposições ou princípios de direito administrativo". Assim, "à luz do art. $1^{\circ}, \mathrm{n}^{\circ} .2$ do RRCEC, não é hoje claro que a dicotomia entre responsabilidade por acto de gestão pública e por acto de gestão privada subsista no âmbito da responsabilidade civil extracontratual." (SOUSA; MATOS, 2009, p. 519). Prima vista, isto estaria a significar o abandono daquela tradicional divisão ${ }^{4}$.

\footnotetext{
2 Aliás, ao encarregar o Gabinete de Política Legislativa e Planeamento de elaborar um projeto de proposta de lei sobre a responsabilidade civil extracontratual, o despacho do Ministério da Justiça fez questão de assinalar que as respectivas ações deviam ser julgadas pelos tribunais administrativos "independentemente de os actos geradores terem sido praticados no âmbito da gestão pública ou privada da Administração".

3 "Art. $4^{\circ}$. Âmbito de jurisdição. 1 - Compete aos tribunais da jurisdição administrativa e fiscal a apreciação de litígios que tenham nomeadamente por objecto: [...] g) Questões em que, nos termos da lei, haja lugar a responsabilidade civil extracontratual das pessoas colectivas de direito público, incluindo a resultante do exercício da função jurisdicional e da função legislativa; $h$ ) Responsabilidade civil extracontratual dos titulares de órgãos, funcionários, agentes e demais servidores públicos".

${ }^{4}$ Neste sentido, antes da vigência do novo regime: Cortez (2002, p. 257- 258), onde aduz: "a nosso ver, o que verdadeiramente está em causa, para efeitos de um regime próprio de responsabilidade civil, não é o tipo de gestão, mas o exercício da função administrativa em si, independente da natureza dos meios empregues e dos sujeitos a quem é confiado. Propomos então - e ao que julgamos saber não estamos sozinhos - a substituição da ideia de gestão pública pela ideia de exercício da função administrativa."
} 
Evidentemente, o texto legal está muito longe de ser "inequívoco" (ANDRADE, 2011b, p. 346). E as coisas ficam ainda mais turvas se considerarmos a ambigüidade (ANDRADE, 2011b, p. 105) do disposto no art. $2^{\circ}, n^{\circ} .2$ da Lei n'. 67/2007: "a presente lei prevalece sobre qualquer remissão legal para o regime de responsabilidade civil extracontratual de direito privado aplicável a pessoas colectivas de direito público". Na verdade, inequívoco era somente o texto da Proposta de Lei $n^{\circ}$. 95/VIII, que tentava especificar as disposições e princípios de Direito administrativo relevantes para efeito de caracterização da função administrativa (ANDRADE, 2011b, p. 346-347). De fato, a versão originária do art. $1^{\circ}, \mathrm{n}^{\circ} .2$ assim versava: "correspondem ao exercício da função administrativa as acções e omissões adoptadas no exercício de prerrogativas de poder público ou reguladas por disposições ou princípios de direito administrativo, impositivos de deveres ou restrições especiais, de natureza especificamente administrativa, que não se aplicam à actuação das entidades privadas" 5 .

Contudo, bem vistas as coisas, a noção de função administrativa trabalhada no novo Regime corresponde materialmente ao tradicional conceito de ato de gestão pública (CADILHA, 2008, p. 112; CADILHA, 2002, p. 236-237). Com efeito, a distinção de partida "parece perdurar entre nós, apesar do desaparecimento da expressão do texto legal aprovado pela Lei $\mathrm{n}^{\circ}$. 67/2007 [...], ainda que a lei não seja inequívoca" (ANDRADE, 2011b, p. 346) ${ }^{6}$. Deste modo, "apesar de algumas vozes discordantes, o legislador manteve a distinção entre actividade de gestão pública e de gestão privada, embora sob outra dominação, como senha de entrada de pedido indemnizatórios junto dos tribunais administrativos"7 (GOMES, 2008, p. 98-99). Aliás, o próprio art. 2º $\mathrm{n}^{\mathrm{o}} .1$ do antigo Decreto-Lei ${ }^{\circ}$. $48051 / 67$ já tratava de vincular o ato de gestão pública

\footnotetext{
5 A opção pela manutenção da diferenciação fica ainda mais evidente na Exposição de Motivos da Proposta de Lei $n^{\circ}$. 95/VIII (COIMBRA, 2002, p. 12-13,18).

6 No mesmo sentido Andrade (2011a, p. 105), Moncada (2006, p. 9, 12, 18-20), onde resume (p. 19): "é certo que se mantém a distinção entre os actos de gestão pública, disciplinados pelo direito público e os actos de gestão privada, disciplinados pelo direito privado, independentemente da natureza da entidade que actua. A Constituição Portuguesa não impede esta distinção legislativa que corresponde ao que é tradicional entre nós". Também, embora críticos: Silva (2003, p. 67), onde afirma que a distinção "parece constar da última versão da proposta do Governo relativa à reforma da responsabilidade civil pública"; Cordeiro, $(2010$, p. 651, 657), onde reconhece que "o RRCEE substitui a anterior 'gestão pública' pela ordenação em função legislativa, função jurisdicional e função político-legislativa."

7 Gomes (2008, p. 86), onde reitera que o art. $1^{\circ}, n^{\circ} .2$ "perpetua a distinção entre actos de gestão pública e actos de gestão privada sob outra designação: acções ou omissões adoptadas no exercício de prerrogativas do poder público, ou reguladas por disposições princípios de direito administrativo."
} 
aos fatos "praticados pelos respectivos órgãos ou agentes administrativos no exercício das suas funções e por causa desse exercício." (PINHEIRO, 2002, p. 83). O novo regime somente assume o esforço analítico de tentar densificar o enevoado sentido material da fluida categoria jurídico-dogmática do ato de gestão pública ${ }^{8}$ (CADILHA, 2008, p. 110). Neste sentido, o "conceito de função administrativa [...] parece implicar a manutenção do regime estabelecido no Código Civil para os actos de gestão privada das pessoas colectivas públicas, embora a lei tenha abandonado essa designação tradicional"9 (ANDRADE, 2008, p. 360 ) e o art. $1^{\circ}, n^{\circ} .2$ do novo regime apenas "recauchutou" o critério utilizado no sistema anterior ${ }^{10}$ (GOMES, 2008, p. 99). Quanto ao art. $2^{\circ}, \mathrm{n}^{\circ} .2 \mathrm{da}$ Lei $\mathrm{n}^{\circ} .67 / 2007$, cabe afirmar que a prevalência nele invocada somente veda a formulação de leis especiais que apliquem às pessoas coletivas públicas um regime de responsabilidade de Direito privado nos casos em que a lei geral não o admita (ANDRADE, 2008, p. 361).

Fixado este horizonte, os atos de gestão pública são aqueles realizados no exercício de um poder público ou de uma posição de autoridade (poderes de coação, no domínio do ius imperii) e sob a regência de normas de direito Administrativo. Já nos atos de gestão privada, a Administração figura como entidade despojada das prerrogativas de autoridade e assume uma posição de paridade com os particulares, realizando atividades alheias à esfera de intervenção do Direito público, vale dizer, atividades não cobertas pela regulação jurídico-administrativa. Em virtude desta relação de horizontalidade, os atos de gestão privada dos entes públicos seguem excluídos do âmbito de incidência do regime de responsabilidade do Direito público e, por conseguinte, continuam sujeitos ao regime de responsabilidade

\footnotetext{
${ }_{8}$ Deste modo, o fator determinante reside na função, não na natureza da entidade (a pessoa jurídica de direito privado também pode exercer a gestão pública, como indica o art. $1, n^{\circ} .5$ da Lei $n^{\circ} .67 /$ 2007). Sobre isto, enfatizando a "manutenção do critério da gestão pública": (GOMES, 2008, p. 98-100).

9 Enfático: Moncada (2006, p. 21) onde destaca que apesar da lata referência legal às disposições ou princípios de direito administrativo, "uma coisa é certa; o diploma apenas abrange os chamados actos de gestão pública, ou seja, os que são disciplinados por normas de direito público administrativo e não os de gestão privada. A lei mantém-se fiel ao entendimento segundo o qual a distinção entre actos de gestão pública e de gestão privada corresponde a um regime jurídico de direito substantivo próprio para cada um deles".

${ }^{10}$ Em todo caso, a questão não deixa de ser duvidosa. Assim: Sousa e Matos (2009, p. 483): "o art. $1^{\circ}$, $\mathrm{n}^{\circ} .2$ RRCEC, ao considerar abrangidas pelo regime legal as acções e omissões 'reguladas por disposições ou princípios de direito administrativo', que são virtualmente todas as acções e omissões administrativas, abre o caminho para a superação substantiva da dicotomia, mas não de modo tão claro que seja neste momento previsível o rumo que vai ser adoptado pela jurisprudência. Assim, o alcance inequívoco da distinção resume-se, hoje, portanto, à responsabilidade contratual."
} 
do Direito privado consagrado nos arts. $483^{\circ}$ a $510^{\circ}$ do Código Civil, com a ressalva contida no art. 501 ${ }^{\circ}$ : "o Estado e demais pessoas colectivas públicas, quando haja danos causados a terceiro pelos seus órgãos, agentes ou representantes no exercício de actividades de gestão privada, respondem civilmente por esses danos nos termos em que os comitentes respondem pelos danos causados pelos seus comissários". Assim, nos termos do art. $500^{\circ}$, o Estado responde direta e objetivamente pelos danos que seus agentes causarem no exercício da função, sem prejuízo do direito de regresso (CADILHA, 2008, p. 110-111; GOMES, 2008, p. 99-100; MONCADA, 2006, p. 17-19; CORDEIRO, 2010, p. 634 e ss).

Apesar da opacidade do texto legal, não deixa de ser nítida a "intenção restritiva" do $n^{\circ} .2$ do art. $1^{\circ}$ do novo regime, pois, em rigor, caberia afirmar que toda a atividade de pessoas coletivas públicas - inclusive a meramente técnica ou de gestão privada - está sujeita, no mínimo, aos princípios gerais da atividade administrativa e às normas do Código de Procedimento Administrativo ${ }^{11}$ concretizadoras de normas constitucionais. Por outros termos ainda: a generalidade das intervenções unilaterais - inclusive as atuações meramente técnicas carentes de coerção ou exercício de autoridade pública - das pessoas coletivas públicas está - segundo a doutrina e a jurisprudência - materialmente submetida ao Direito Administrativo, bastando a "atribuição pública" e o "enquadramento institucional". Neste horizonte, além dos casos de acidentes de trânsito com veículos públicos em circulação normal, na prática pouco parece restar excluído do âmbito de incidência do novo regime (ANDRADE, 2008, p. 360-361). Trata-se de um entendimento fortemente limitador do alcance da gestão privada referente às pessoas coletivas públicas ${ }^{12}$ (ANDRADE, 2011b, p. 346).

Desta forma, a única mudança significativa neste âmbito deriva do Estatuto dos Tribunais Administrativos e Fiscais (LISBOA, 2002) e refere-se à unidade de jurisdição nas ações de responsabilidade civil extracontratual do Estado e das demais entidades públicas. No mais, à tradicional distinção entre ato de gestão pública e ato de gestão privada restam duas relevantes tarefas. Primeiramente, em virtude da manutenção da separação de regimes de responsabilidade consoante o ato seja praticado sob o domínio do Direito público

\footnotetext{
${ }^{11}$ V.g., o seu art. $2^{\circ}, \mathrm{n}^{\circ} .5$, expressamente aplicável a "toda e qualquer actuação da Administração Pública, ainda que meramente técnica ou de gestão privada".

${ }^{12}$ Segundo a visão doutrinária e jurisprudencialmente dominante, a atuação no seio das entidades de Direito público vai presumida como de gestão pública.
} 
ou Direito privado, a clivagem em análise define o Direito material aplicável ao caso concreto. Em segundo lugar, a diferenciação assume relevância também no momento de definir a competência do tribunal administrativo nos casos de "responsabilidade civil extracontratual dos sujeitos privados aos quais seja aplicável o regime específico da responsabilidade do Estado e demais pessoas colectivas de direito público" (ETAF, art. $\left.4^{\circ}, \mathrm{n}^{\circ} .1, i\right)$, pois será necessário saber se o ato danoso encarna ou não o exercício de prerrogativas de autoridade (CADILHA, 2008, p. 111).

Em síntese, o quadro teleológico-normativo acima exposto conduz ao reconhecimento da manutenção da distinção entre ato de gestão público e ato de gestão privada como o ponto de partida da estrutura lógico-analítica da responsabilidade civil extracontratual do Estado e demais entidades públicas. Questão diversa e não menos relevante - ao menos desde a perspectiva de uma dogmática minimamente consciente de sua tarefa de crítica do estabelecido de iure constituto - reside em saber se esta diferença substancial deveria ou não permanecer.

De todo o modo, cabe dizer que a conservação desta clivagem conceitual está longe de merecer elogios ${ }^{13}$. Na verdade, ela atravessa uma intensa "crise" (MEDEIROS, 2005, p. 70) dogmática. Primeiramente, a distinção assume como premissa o funesto resquício de uma ideia autoritária de Administração, que ou exercia poderes de autoridade mediante atos administrativos - segundo uma leitura "actocêntrica" das formas de intervenção administrativa - ou era subsidiariamente conduzida ao "limbo" do Direito privado. Nesta perspectiva, o Direito administrativo figura como mero sistema de normas excepcionais, simplesmente exorbitantes do Direito civil (SILVA, 2003, p. 62).

Em segundo termo, a distinção soa artificial e cria uma desnecessária separação de fronteiras pouco claras, suscitando diversos problemas de qualificação jurídica (ANDRADE, 2011b, p. 347). Com efeito, faltam critérios suficientemente sólidos e nítidos para determinar as esferas em confronto ${ }^{14}$.

${ }^{13}$ Contra, defendendo a coerência da tradicional distinção: Moncada (2006, p. 19 e s.).

${ }^{14}$ Por isso não causa estranheza o fato de a jurisprudência ter chegado inclusive a abandonar o tradicional critério de delimitação entre gestão pública e gestão privada, assentando a clivagem decisiva na ideia de "ambiente de trabalho". Na ocasião, o problema residia em saber se o erro médico cometido no exercício privado da medicina em um hospital público pelos médicos ao seu serviço deveria conduzir à responsabilidade em virtude de gestão pública ou à responsabilidade em virtude de gestão privada. Assim: Silva (2003, p. 63), onde aponta que esta lógica "impressionista" significa a renúncia na busca das características essenciais e o contentamento com "qualquer cheiro de Direito Público". Ainda informativo: Andrade (2011a, p. 105). 
E a diferenciação resulta praticamente impossível no âmbito das atuações técnicas ou materiais da Administração (v.g., as actividades de médicos, engenheiros e motoristas não se diferenciam consoante realizadas no serviço público ou no serviço privado). Como indicado acima, hoje todas as atividades administrativas tendem a ser unificadas não mais em torno da regra formal do exercício de autoridade, mas à luz da ideia material de função administrativa. Por outros termos ainda: o decisivo está na dimensão substancial ou teleológica da satisfação de necessidades coletivas mediante formas de atuação públicas ou privadas. Ademais, a distinção não deixa de ser injusta, na medida em que cria inúteis dúvidas quanto ao Direito material aplicável, um imbróglio de regimes que - desde a perspectiva das garantias do cidadão - deixa muito a desejar em virtude de sua fragilidade e insegurança. Debilidades estas que deveriam conduzir à uniformização do regime jurídico ${ }^{15}$.

Em terceiro lugar, ao dispor que o comitente (aquele que encarrega outrem de qualquer atuação específica) apenas responde se sobre o comissionário (o encarregado de qualquer atuação específica pelo comitente) recair a obrigação de indenizar (vale dizer, em regra, se este tiver atuado com culpa), o regime civil atribuído ao ato de gestão privada não deixa de encarnar uma espécie de responsabilidade pelo fato de outrem, assumindo uma concepção de responsabilidade do Estado completamente ultrapassada. Com efeito, neste horizonte, a responsabilidade pública em virtude de atos de gestão privada não passa da antiga responsabilidade indireta, vale dizer, da mera responsabilidade para garantia dos terceiros lesados: o Estado e os demais entes públicos não seriam, por si próprios, diretamente responsáveis, mas somente garantidores - no âmbito das relações externas - da ressarcibilidade do dano causado através do fato ilícito culposo de seus agentes, considerados como se terceiros fossem. Uma compreensão absolutamente incompatível com a intencionalidade axiológico-normativa da Constituição Portuguesa, cujo art. $22^{\circ}$ pressupõe, incontornavelmente, que as entidades públicas sejam, elas

\footnotetext{
${ }^{15}$ Embora a reforma do contencioso administrativo tenha eliminado os problemas de morosidade e de denegação da justiça (com grave e intolerável lesão ao direito fundamental à tutela jurisdicional efetiva) resultantes dos frequentes conflitos de competência instaurados sob a égide do modelo anterior. Sobre tudo isto: Silva, $(2003$ p. 62, 64), onde destaca a necessidade de uma total eliminação da "manta de retalhos" ou do "labirinto jurídico" extremamente nefasto do ponto de vista da garantia dos cidadãos e da substituição de critérios de "poder" por critérios "teleológicos" conduzentes à aplicação de um regime de responsabilidade unitário "sempre que estejam em causa o exercício da função administrativa (independentemente da natureza jurídica dos sujeitos causadores do dano)". Também crítico: Cordeiro (2010, p. 643): "materialmente, a destrinça não é possível. Tornava-se necessário indagar o complexo normativo invocado pelo Estado para agir, ou melhor, para ter agido. O sistema era formal e muito imprevisível."
} 
mesmas, diretamente responsáveis pela atividade de seus funcionários no exercício de suas funções ${ }^{16}$.

Por último, a remissão para a disciplina do Direito privado significa recorrer a um regime de responsabilidade civil absolutamente defasado, porque alheio às exigências da atual realidade das relações jurídico-administrativas. Com efeito, o regime do Direito civil ignora ou considera de forma insuficiente não só as peculiaridades do tratamento de algumas questões nucleares no terreno jurídicopúblico, mas também as especificidades da responsabilidade das pessoas coletivas públicas, como a chamada "culpa de serviço" e a tendencial objetivização neste marco (em virtude do risco ou inclusive em razão de danos licitamente causados) (ANDRADE, 2011b, p. 347; SILVA, 2003, p. 65-66).

Em síntese, o abandono da dualidade de jurisdições (em razão do novo contencioso administrativo estabelecido no ETAF) não significou o abandono da dualidade de regimes jurídico-materiais, de modo que, mesmo com o advento da Lei n 67/2007, a determinação do Direito substancial aplicável continua a exigir a distinção entre atos de gestão pública e atos de gestão privada - "seja lá o que isso for" (SILVA, 2003, p. 65). Vale dizer: a unificação neste plano significou apenas "certeza e segurança em matéria adjectiva, já no tocante à indagação do conteúdo dos direitos das partes, a atribuição, só por si, não chega para celebrar definitivamente a paz jurídica" 17. Por outro lado, "não se vislumbra, no entanto, qualquer razão para manter a diferença de regimes substantivos de responsabilidade entre a gestão pública e a gestão privada no âmbito da actuação das pessoas colectivas públicas" "18 (ANDRADE, 2011b, p. 347).

\footnotetext{
${ }^{16}$ Para esta crítica: Andrade (2011b, p. 347), onde arremata: este desvio "faz recair sobre a manutenção do regime do Código Civil a suspeita de desconformidade constitucional". No mesmo sentido: Cordeiro (2010, p. 644-648), onde considera que a remissão para a responsabilidade do comissário pressupõe uma compreensão incompleta da personalidade coletiva e admite a possibilidade de uma "correção" científica do esquema do art. $501^{\circ}$ do CC. Para uma tentativa de adaptação, defendendo a interpretação do arts. $500^{\circ}$ e $501^{\circ}$ do CC conforme o art. $22^{\circ}$ da Constituição Portuguesa: Sousa e Matos $(2009$, p. 517 e s). Entretanto, como bem destaca Andrade (2011b, p. 347), "essa adaptação não é possível sem desvirtuar o sentido dos preceitos do Código Civil."

${ }^{17}$ Ainda no campo de preparação do novo regime: Pinheiro (2002, p. 69-70), onde acrescenta: "surge então a melindrosa questão jurídica do direito aplicável, e o alcance da pacificação que se pretendeu com este contencioso por atribuição pode desvanecer-se se o legislador não encontrar fórmulas simples e suficientemente identificadoras dos dois tipos de responsabilização. A manter-se a dualidade de regimes jurídicos tão diferenciados, apenas se deslocará o pomo da discórdia, do tribunal competente em razão da matéria para o direito aplicável."

${ }^{18}$ Ainda: Cortez (2002, p. 257): "num tempo em que, especialmente no contexto de uma administração constitutiva, é frequente o recurso a fórmulas organizatórias jurídico-privadas, i.e., à criação de entidades privadas fictícias ou de mão pública, que formam uma Administração paralela, mais eficaz porque liberta de certos controlos públicos; num tempo em que é frequente o uso de meios privatísticos, designadamente na gestão de estabelecimentos públicos; por fim, num tempo em que se assiste a um aumento exponencial da contratualização da actividade administrativa com privados, fará sentido manter essa bipartição?" No mesmo sentido: Medeiros, Rui. Responsabilidade civil dos poderes públicos, p. 50.
} 


\section{O MODELO DE REPARTIÇÃO DA RESPONSABILIDADE ENTRE A ORGANIZAÇÃO E O AGENTE PÚBLICO}

Se longe vão os tempos de irresponsabilidade do Estado (sistema de garantia administrativa) ${ }^{19}$ a segunda questão lógico-estrutural no âmbito da responsabilização civil extracontratual dos entes públicos em virtude dos danos ilicitamente causados ao administrado reside em definir o modo e os critérios de distribuição desta responsabilidade.

Como se sabe, o Estado não dispõe de um aparato bio-psíquico próprio, devendo manifestar sua vontade através dos chamados "agentes públicos" (titulares de órgãos, funcionários, trabalhadores e quaisquer pessoas dos serviços das pessoas coletivas públicas), os únicos capazes de atuar nas concretas situações da vida e realizar os fins ligados ao bem comum. É precisamente em razão deste necessário liame de imputação - a envolver uma pluralidade de sujeitos (pessoas) discursivamente relevantes (Estado e servidores) - que o problema da repartição de responsabilidade se coloca (ANDRADE, 2008, p. 362). Ainda sobre a questão: Cortez (2002, p. 258-260). Neste contexto, urge saber quem é o "sujeito da imputação" (GOMES, 2008, p. 30).

Ninguém ignora que a situação capaz de deflagrar a responsabilização extracontratual do Estado no exercício da função administrativa envolve necessariamente três sujeitos, reunidos em dois pólos. De um lado estão a Administração Pública e o servidor. Da outra banda está o lesado. No plano das "relações externas", interessa saber quem responde diretamente ${ }^{20}$ (CADILHA, 2008, p. 230-232) em face do administrado lesado (em virtude do output danoso a sua esfera de organização), se a Administração Pública ou seu servidor. Já o plano das "relações internas" cuida das consequências da responsabilidade direta e externa no seio das relações entre Administração e funcionário - imposição de sanção disciplinar e exercício de direito de regresso contra o servidor (CANOTILHO, 1974, p. 71; GOMES, 2008, p. 32, 42, 43-45; CORTEZ, 2002, p. 258-259).

\footnotetext{
${ }^{19}$ A Constituição Portuguesa de 1976 consagrou o princípio da responsabilidade civil solidária da Administração e de seus servidores como direito fundamental do administrado (arts. $22^{\circ}$ e $17^{\circ}$ ) e vedou categoricamente a garantia administrativa (art. 271, $\mathrm{n}^{\circ}$. 1). Para a evolução histórica neste âmbito: Sousa e Matos (2009, p. 478-481); Moncada (2006, p. 13-15).

${ }^{20}$ Segundo o art. 22 da Constituição Portuguesa, a responsabilidade do Estado deve ser sempre direta, como corolário do princípio do Estado de Direito. Sobre isso: Moncada (2006, p. 10, 13, 27, 57); Cordeiro (2010, p. 646-647); Andrade (2011b, p. 347).
} 
Esta distribuição ou repartição de responsabilidades arranca de dois critérios fundamentais. Primeiramente, existe um "fator de delimitação" (ANDRADE, 2008, p. 362) a convocar a distinção entre responsabilidade institucional ou funcional (do Estado) e responsabilidade pessoal ou individual (do funcionário) (CANOTILHO, 1974, p. 64, 71-72). Além disso, este mesmo fator de delimitação exige ainda a distinção entre atos ou faltas pessoais (atuação fora do exercício das funções) e atos ou faltas funcionais (atuação dentro do exercício das funções $)^{21}$. Para efeitos de responsabilidade civil extracontratual do Estado, interessam somente os danos causados pelos agentes públicos no exercício de suas funções e por causa deste exercício ${ }^{22}$. Os danos que estes agentes causam fora do exercício de suas funções ou causados no exercício das funções mas não por causa desse exercício estão sujeitos ao regime de responsabilidade do Direito privado (GOMES, 2008, p. 32-99; CADILHA, 2008, p. 110; CADILHA, 2002, p. 237). Em segundo lugar, o chamado "fator de atribuição" assume uma forte carga axiológica referida à modalidade ou ao grau do desvio subjetivo do servidor (culpa leve, culpa grave e dolo) (ANDRADE, 2008, p. 362-363; MONCADA, 2006, p. 17). Da combinação entre ambos os critérios emergem as diversas possibilidades de repartição de responsabilidade.

Segundo o modelo consagrado nos arts. $2^{\circ}$ e $3^{\circ}$ do Decreto-Lei ${ }^{\circ} .48051 /$ 67, existiam quatro formas de repartição de responsabilidade entre a Administração e seus servidores: (i) responsabilidade exclusiva da Administração, sem direito de regresso contra o funcionário (ato funcional com culpa leve); (ii) responsabilidade exclusiva da Administração, com direito de regresso contra o servidor (ato funcional com culpa grave); (iii) responsabilidade solidária entre Administração e servidor (ato funcional doloso); (iv) responsabilidade exclusiva

\footnotetext{
${ }^{21}$ Sobre a distinção entre "atos pessoais" (comportamentos do servidor realizados fora do exercício das funções ou no exercício das funções mas não por causa desse exercício, os quais sujeitam o funcionário à responsabilidade estabelecida no regime geral do Direito privado) e "responsabilidade pessoal" (decorrente de atos lesivos praticados no exercício de funções e por causa desse exercício, mas pelos quais o servidor responde pessoalmente, ainda que em forma solidária com o Estadoadministrador): Cadilha (2008, p. 108-110); Cadilha (2002, p. 237, 239). No mesmo sentido, distinguindo, de um lado, entre "atuações funcionais" e "atuações pessoais", e, de outro, entre "responsabilidade pessoal" e "responsabilidade da entidade administrativa" (com a admissão da coexistência de ambas no âmbito das atuações funcionais): Medeiros (2005, p. 71). Ainda sobre a diferença entre atos funcionais e atos pessoais: Andrade (2011a, p. 105-106); Mesquita (2004, p. $68,70)$; Gomes, (2008, p. 99). Aliás, trata-se de uma distinção mantida nos arts. $22^{\circ}$ e $271^{\circ}$ da Constituição Portuguesa: Silva (2004, p. 148).

${ }^{22}$ Sousa e Matos (2009, p. 485): "o critério relevante é o da imputação: há responsabilidade administrativa pelos prejuízos provocados por actos que sejam imputados a uma pessoa colectiva administrativa (actos funcionais)".
} 
do funcionário (ato pessoal, realizado fora dos limites da função) (CADILHA, 2002, p. 237-238; CADILHA, 2008, p. 109-110; SILVA, 2004, p. 148-149).

Entretanto, a escassa significância concedida na legislação ordinária à figura da solidariedade entre Administração e servidor contrariava o princípio da responsabilidade civil solidária contida no art. $22^{\circ}$ da Constituição Portuguesa. Este desvio conduziu não apenas a sérias dúvidas sobre a constitucionalidade dos arts. $2^{\circ}$ e $3^{\circ}$ do Decreto-Lei $n^{\circ} .48051$, mas também à urgente necessidade de reconstrução do esquema de distribuição da responsabilidade (AMARAL, 2002, p. 46; QUADROS, 2002, p. 59-60; CADILHA, 2002, p. 236-237). Tal reformulação teve lugar através dos arts. $7^{\circ}$ e $8^{\circ}$ da Lei $n^{\circ} .67 / 2007^{23}$.

Neste novo quadro normativo, as possibilidades de responsabilização são as seguintes: $(i)$ responsabilidade exclusiva do Estado-administração, nos casos de culpa funcional leve do servidor ( $\operatorname{art} .7^{\circ}, \mathrm{n}^{\circ} .1$ ), bem como nas hipóteses de responsabilidade objetiva resultantes da violação de normas em procedimentos de formação de contratos de empreitada e concessão de obras públicas, de prestação de serviços e de fornecimento de bens (art. $7^{\circ}, \mathrm{n}^{\circ} .2$ ) ou do funcionamento anormal do serviço (art. $7^{\circ}$, n. $^{\text {os }} 3$ e 4); (ii) responsabilidade solidária entre servidor e Administração, nas hipóteses de atos ilícitos realizados no exercício das funções e por causa desse exercício, com dolo ou culpa grave do agente público (art. $8^{\circ}$, n. $^{\text {os }} 1^{\circ}$ e $2^{\circ}$ ); (iii) responsabilidade exclusiva do agente público, nos casos de danos resultantes de "falta pessoal" ou "atuação não funcional" (atos realizados fora das funções) (ANDRADE, 2008, p. 363-364; GOMES, 2008, p. 35-42, 109-110; CADILHA, 2008, p. 109-110).

De início, ao estender o campo de aplicação do regime de responsabilidade solidária ao domínio das condutas praticadas com culpa grave ${ }^{24}$, o novo regime atende mais e melhor às exigências do princípio da solidariedade consagrado no art. 22 da Constituição (SILVA, 2004, p. 160-161). O fundamento desta ampliação não deixa de ser evidente: a necessidade de reforçar a garantia dos particulares em face do Estado, aumentando as chances de ressarcimento dos danos sofridos, uma derivação do princípio constitucional da tutela efetiva do

\footnotetext{
${ }^{23}$ Em todo caso, o direito à indenização consagrado no art. 22 da Constituição Portuguesa tem a natureza de direito fundamental e por isso é imediatamente aplicável mesmo na ausência de legislação ordinária concretizadora (arts. $17^{\circ}$ e 18): Moncada (2006, p. 25); Silva (2003, p. 60); Cordeiro (2010, p. 656); Silva (2004, p. 159, 177); Mesquita (2004, p.123-124).

${ }^{24}$ Cabe destacar que o novo regime assume a tendência de diluição da culpa no conceito de ilicitude. Sobre isso: Andrade (2011b, p. 349), onde resume: "estamos perante uma desvalorização da ideia de culpa pessoal, subjetiva ou 'psicológica' do agente, mas não necessariamente perante a desvalorização da ideia de culpa como censura ética”.
} 
cidadão (Constituição Portuguesa, art. 268 ${ }^{\circ}$ n $^{\circ}$. 4) (MONCADA, 2006, p. 27). O que, em última instância, desde uma perspectiva de psicologia social, não deixa de contribuir para o aperfeiçoamento do serviço. Todavia, nada parece excluir, desde o início e com segurança, a possibilidade de que esta ampliação acabe, inversamente, por prejudicar o dinamismo e a eficiência administrativa, ao permitir que os particulares mais agressivos ou menos esclarecidos possam arbitrária ou negligentemente invocar a existência de culpa grave e deste modo obrigar o funcionário a comparecer a um tribunal, assim perturbando o normal desempenho de suas atividades. Ou ainda pior: a previsão de responsabilidade solidária pode ser maliciosamente utilizada como meio de pressionar ou coagir o funcionário (antes de sua atuação) através da ameaça de instauração do respectivo processo (ANDRADE, 2008, p. 363-364). Em todo caso, trata-se de um perigo assumido na cost-benefit analysis subjacente à lógica consequencialista do novo regime ${ }^{25}$.

Em segundo termo, ao consagrar agora a figura da "culpa anônima" ou "culpa do serviço" (faute du service), o legislador nada mais faz do que elevar à textualidade legal uma forma de imputação que já era reconhecida no plano da translegalidade através do rico trabalho criador da jurisprudência, com base nos princípios gerais do Direito. Em todo caso, ao deixar evidente a intenção de evitar uma "irresponsabilidade organizada", o novo regime oferece um considerável ganho em termos de segurança jurídica, pois garante ao lesado uma tutela efetiva naquelas situações em que a identificação do curso causal no seio da organização estatal e a prova da culpa de seus agentes for extraordinariamente difícil ou mesmo impossível na prática (probatio diabolica $)^{26}$.

Por outro lado, embora o art. $22^{\circ}$ da Constituição não diferencie graus de ilicitude e de culpa, não contraria as exigências constitucionais a manutenção da responsabilidade exclusiva do Estado em virtude de danos resultantes da

\footnotetext{
${ }^{25}$ Enquanto os consequencialistas definem a correção moral de uma ação em função da qualidade de seus resultados segundo um global juízo de ponderação, os dentologistas definem a correção moral de uma ação em virtude de seu valor em si mesma enquanto imponderável estabelecido através de uma norma. Sobre a diferença no terreno da filosofia moral e da argumentação ético-jurídica em geral: Neumann (1994, p. 81 e s.); Greco (2009, p. 120 e s).

${ }^{26}$ De qualquer modo, não deixa de ser uma hipótese de responsabilidade objetiva por atos ilícitos, ou seja, um desvio em relação à regra da responsabilidade sustentada na ilicitude culposa. E ao qualificar como ilícita a ofensa resultante destes casos, o legislador aloca no plano da ilicitude uma questão outrora tematizada no plano da culpa. Para o efeito, o art. $7^{\circ}, \mathrm{n}^{\circ} .4^{\circ}$ adota um standard objetivo de definição do razoavelmente exigível em termos de qualidade do serviço (padrões médios de resultado). Sobre tudo isso: Andrade (2008, p. 363, 366. Ainda: Moncada, (2006, p. 57 e s).
} 
atuação funcional ilícita e culposa de seus agentes, hipótese de imputação agora restrita aos casos de culpa funcional e leve. Seu fundamento, entretanto, reside não em qualquer resquício da já distante e funesta "garantia administrativa", mas nos princípios do Estado de Direito ${ }^{27}$. De um lado, a necessidade de garantir um mínimo de eficiência e dinamismo da intervenção do Estado-administrador (Constituição Portuguesa, arts. 266 ${ }^{\circ}, \mathrm{n}^{\circ} .1$ e $267^{\circ}, \mathrm{n}^{\circ}$. 2) conduz não só a estimular o "gosto pela decisão", mas também a afastar o perigo de paralisação da atividade administrativa, evitando a proliferação de servidores acanhados, medrosos e burocratas, refugiados na cega ou apática satisfação das práticas rotineiras ${ }^{28}$ (ANDRADE, 2008, p. 364). Por outro lado, a imputação das faltas leves exclusivamente ao Estado configura um derivado da dignidade humana e do princípio da proporcionalidade: só faltas com um determinado grau de culpa devem onerar o servidor, que segue como um ser humano suscetível de atuar em erro, eventualmente desculpável se não reiterado ${ }^{29}$.

Além disso, a hipótese de atos não funcionais continua a receber o mesmo tratamento concedido aos atos de gestão privada, ficando, assim, excluída do regime da Lei $n^{\circ}$. 67/2007. Com efeito, os atos de servidores praticados fora do exercício das funções ou no exercício das funções mas não por causa deste exercício configuram meros atos pessoais e conduzem à responsabilidade individual do agente segundo o regime geral do Direito privado ${ }^{30}$. Embora a lei mencione somente os casos de dolo ou culpa grave do funcionário (art. $8^{\circ}, \mathrm{n}^{\mathrm{os}}$ $1^{\circ}$ e $\left.2^{\circ}\right)$, também a culpa leve está em condições de fundamentar a

${ }^{27} \mathrm{O}$ art. $271^{\circ}$ da Constituição Portuguesa apenas exclui a regra da garantia administrativa (independência de autorização hierárquica), não significando que os funcionários sejam sempre responsáveis de alguma forma. A norma não exclui nem o regime de solidariedade, nem a possibilidade de que em certas circunstâncias o Estado venha a ser exclusivamente responsável. Para a compatibilização entre o art. $271^{\circ}$ e o art. 22 da Constituição: Moncada, (2006, p. 50 e 51).

${ }^{28}$ Ainda: Moncada (2006, p. 30): "justifica-se perfeitamente esta solução porque as entidades públicas não podem exigir ser servidas sempre pelos melhores e da melhor maneira, sob pena de inoperância dos serviços públicos, o que reverteria até contra os particulares".

${ }^{29}$ Gomes (2008, p. 35). No mesmo sentido: Moncada (2006, p. 28): "a solidariedade só faz sentido havendo fato ilícito doloso ou gravemente culposo daqueles, pois que neste caso não é curial que seja apenas a comunidade a suportar através das receitas públicas o custo indemnizatório".

${ }^{30}$ Ao contrário da "falta funcional", a chamada "falta pessoal" resulta do exercício de atos (realizados dentro ou fora das horas de expediente) de instrumentalização do cargo em favor de metas exclusivamente individuais (com a mera aparência de função) e não ingressa no âmbito da jurisdição administrativa, devendo ser sindicada perante os tribunais civis. A título de ilustração, basta imaginar o caso do motorista de um ministro que utiliza o veículo de serviço para passear e fazer compras para sua casa ou ainda o agente policial que utiliza sua arma de serviço para um acerto de contas privado. Assim: Gomes (2008, p. 99-100). No mesmo sentido: Cadilha (2008, p. 109-110); Cadilha (2002, p. 237-238). 
responsabilidade exclusiva do agente público em virtude de danos resultantes de atuações não funcionais, uma vez que as entidades públicas apenas respondem pelos danos decorrentes de atuações funcionais - "no exercício das funções e por causa desse exercício" (art. $7^{\circ}, \mathrm{n}^{\circ} .1$ e art. $8^{\circ}, \mathrm{n}^{\circ} .2$ ) (ANDRADE, 2008, p. 364; GOMES, 2008, p. 99-100; MONCADA, 2006, p. 17-31; CADILHA, 2008, p. 110).

Afinal, trata-se da consolidada e comezinha ideia de que segue "incontroversa a responsabilidade exclusiva do agente público, autor de condutas ilegais e culposas manifestamente exteriores e independentes de suas funções. Não oferece dúvidas de que, se um funcionário, ao atuar como cidadão, provocar um dano temporal, espacial ou funcionalmente não conexionado com o serviço, não pode esperar uma proteção patrimonial da administração nem o particular poderá acionar outra entidade que não o agente lesante" (CANOTILHO, 1974, p. 64).

Por último, também merece aplauso o esforço no sentido de tornar obrigatório (art. $6^{\circ}, \mathrm{n}^{\circ} .1$ ) o exercício do direito de regresso. Pois este dever não só tende a elevar o nível de diligência e cuidado dos agentes, como na prática também garante que o erário público apenas responda subsidiariamente em virtude dos danos causados por incúria ou desleixo dos servidores em face de seus deveres funcionais ${ }^{31}$. Contudo, resta saber ${ }^{32}$ se esta exigência vale também relativamente às entidades privadas sujeitas ao novo regime $\left(\operatorname{art.} 1^{\circ}, n^{\circ} .5\right)$. Parece razoável responder negativamente à questão, pois o contrário seria justificar uma desproporcional restrição da autonomia de gestão e patrimonial dos particulares. E inexiste um interesse público ou qualquer outra razão material capaz de legitimar semelhante dever (ANDRADE, 2008, p. 364-365).

\section{CONSIDERAÇÕES FINAIS}

Relativamente à clivagem conceitual lógico-analiticamente estruturante do regime legal da responsabilidade civil extracontratual do

\footnotetext{
${ }^{31}$ Contudo, trata-se de um dever imperfeito, pois o regime não prevê nenhuma sanção jurídica para a hipótese de descumprimento. De qualquer forma, as consequências financeiras da inobservância do dever serão controláveis pela intervenção do Tribunal de Contas. Sobre tudo isso, com análise das diversas possibilidades de demanda à disposição do lesado: Gomes (2008, p. 30, 31, 46 e s).

${ }^{32}$ Tirante a exceção no caso de direito de regresso contra os magistrados no seio da responsabilidade pelo exercício da função jurisdicional (art. 14, $\mathrm{n}^{\circ}$. 2). Desvio este, aliás, pouco comprensível: Mesquita (2004, p. 16).
} 
Estado no exercício da função administrativa, as dificuldades teóricas e práticas identificadas através dos esforços da doutrina e da jurisprudência se refletem na timidez ou mesmo hesitação do legislador em manter a distinção entre atos de gestão privada e atos de gestão pública como eixo da nova sistemática. Se por um lado, "contrariando algumas vozes, o legislador não prescindiu da distinção entre 'gestão pública' e 'gestão privada', embora tenha abandonado esta terminologia" (GOMES, 2008, p. 28), por outro "perde interesse a distinção (CORDEIRO, 2010, p. 644). Neste horizonte, tendo em vista a necessidade e a conveniência de um "entrelaçamento entre o art. $4^{\circ}, \mathrm{n}^{\circ} .1, g$ do ETAF e a LRCEE" (GOMES, 2008, p. 29), teria sido mais razoável abrir mão desta artificial e indeterminada diferenciação.

Para efeitos teóricos e práticos, a uniformização da jurisdição administrativa no terreno da responsabilidade extracontratual do Estadoadministrador (através da reforma do contencioso administrativo) deveria ter sido acompanhada da uniformização do regime jurídico da responsabilidade civil dos entes públicos. Somente esta reunião de esforços estaria em condições de realizar a intenção originária do legislador, de garantir coerência ao espírito do sistema de justiça administrativa e oferecer um suficiente grau de certeza/segurança às legítimas pretensões do cidadão lesado. Em termos mais diretos, mas não menos rigorosos: "as mudanças introduzidas pela reforma do contencioso administrativo pressupõem a alteração do regime da responsabilidade civil pública, não fazendo qualquer sentido a presente dualidade de regimes jurídicos substantivos, cuja distinção não só carece de lógica, como também corresponde à aplicação de regimes jurídicos inadequados à realidade social e jurídica dos nossos dias" (SILVA, 2003, p. 66-67).

Quanto ao esquema lógico-analítico de repartição de responsabilidade entre os sujeitos discursivamente relevantes (Estados e seus funcionários), o novo regime garante total efetividade ao art. $22^{\circ}$ da Constituição. Resta saber, se na lógica consequencialista subjacente ao modelo legislativamente adotado, os resultados serão mesmo sustentáveis em termos de cost-benefits analysis. Pois se abre um "leque de hipóteses em que o cidadão-lesado ficará a ganhar relativamente ao sistema antigo. Mas o cidadão-contribuinte fica certamente a perder com tamanha e voluntariosa abertura. O risco é evidente: quando o Estado paga, pagamos todos" (GOMES, 2008, p. 91). Sobretudo em uma época de recursos públicos cada vez mais escassos e de 
falência do Estado Social ${ }^{33}$. Mas assim como a colonização do Direito pela argumentação consequencialista não deixa de ser um lastimável sinal dos tempos ${ }^{34}$, também ele, o tempo, dirá se os resultados serão ou não suportáveis.

\section{REFERÊNCIAS}

AMARAL, Freitas do. Intervenção. In: COIMBRA. Ministério da Justiça. Responsabilidade civil extra-contratual do Estado. Coimbra: Ed. Coimbra, 2002. p. 43-51. Trabalhos preparatórios da reforma.

ANDRADE, José Carlos Vieira. A Justiça Administrativa (Lições). 11. ed. Coimbra: Almedina, 2011a.

A responsabilidade indenizatória dos poderes públicos em 3D: estado de direito, Estado fiscal e Estado social. Revista de Legislação e Jurisprudência, n. 3969, p. 345-363, 2011 b.

A responsabilidade por danos decorrentes do exercício da função administrativa na nova lei sobre responsabilidade civil extracontratual do Estado e demais entes públicos. Revista de Legislação e Jurisprudência, n. 3951, p. 360-371, 2008.

CADILHA, Carlos Alberto Fernandes. Regime da responsabilidade civil extracontratual do estado e demais entidades públicas anotado. Coimbra: Almedina, 2008.

Responsabilidade da administração pública. In: COIMBRA. Ministério da Justiça. Responsabilidade civil extra-contratual do Estado. Coimbra: Ed. Coimbra, 2002. p. 235-256. Trabalhos preparatórios da reforma.

\footnotetext{
${ }^{33}$ Certo é que a prevenção e a repressão da "má-gestão" das entidades públicas devem considerar o instrumental da responsabilidade civil não como prima ou sola, mas como ultima ratio a ser subsidiariamente invocada em relação às novas técnicas de gestão pública (new public management), encarregadas de deslocar o parâmetro da atuação do Estado da ideia de legalidade para a ideia de desempenho. Assim: Nabais (2009, p. 732-733). No mesmo sentido, destacando a perigosa inclinação para uma "responsabilidade seguradora" ou um "Estado Providência fora do tempo": Andrade (2008, p. 370).

${ }^{34}$ Costa (2008, p. 409): "se tudo se tem de reconduzir a um pensamento eficaz, se tudo se tem de medir pela eficácia, pelos resultados - resultados esses previamente definidos como aqueles que se têm de atingir e que alguém teve que definir, o que não deixa de ser interessante, porquanto nos devemos interrogar sobre a legitimidade daqueles que os definem - , então, tudo o que for socialmente relevante tem de se submeter ao império desse pensamento global e esmagador que assume como tarefa primeira a realização daquilo que é eficaz. Perante isto é lícito perguntar: qual o território do pensar e do agir humanos onde se possa levar a cabo a justiça, sobretudo quando esta não for eficaz?"
} 
CANOTILHO, Joaquim José Gomes. O problema da responsabilidade do estado por actos lícitos. coimbra: almedina, 1974.

CORDEIRO, António Menezes. A responsabilidade civil do Estado. O Direito, Coimbra, v. 142, n. 4, p. 623-658, 2010.

CORREIA, Fernando Alves. A indemnização pelo sacrifício: contributo para o esclarecimento do seu sentido e alcance. Revista de Legislação e Jurisprudência, n. 3966, p. 143-161, 2011.

CORTEZ, Margarida. Contributo para uma reforma da lei de responsabilidade civil da Administração. In: COIMBRA. Ministério da Justiça. Responsabilidade Civil Extra-Contratual do Estad $o$. Coimbra: Ed. Coimbra, 2002. p. 257-264. Trabalhos preparatórios da reforma.

COSTA, José de Faria. O direito, a linguagem e a terceira pessoa. In: NUNES, António José Avelãs et al. (Coord.). O direito e o futuro do direito. Coimbra: Almedina: Coimbra, 2008. p. 497-511.

GOMES, Carla Amado. Três textos sobre o novo regime da responsabilidade civil extracontratual do estado e demais entidades públicas. Lisboa: aafdl, 2008.

GRECO, Luís. Lebendiges und totes in feuerbachs straftheorie ein beitrag zur gegenwärtigen strafrechtlichen grundlagendiskussion. Berlin: Duncker \& Humblot, 2009.

LISBOA. Lei n. ${ }^{\circ}$ 13/2002, de 19 de fevereiro. Estatuto dos Tribunais Administrativos e Fiscais Lisboa: PGDL, 2002

MEDEIROS, Rui. Responsabilidade civil dos poderes públicos. Lisboa: Ed. Universidade Católica, 2005.

MESQUITA, Maria José Rangel de. Da responsabilidade civil extracontratual da Administração no ordenamento jurídicoconstitucional vigente. In: QUADROS, Fausto de (Coord.)

Responsabilidade civil extracontratual da administração pública. 2. ed. Coimbra: Almedina, 2004. p. 39-134.

O regime da responsabilidade civil extracontratual do Estado e demais entidades públicas e o direito da União Européia. Coimbra: Almedina, 2009. 
MONCADA, Luís Cabral de. A responsabilidade Civil Extracontratual do Estado e demais Entidades Públicas. Lisboa: Faculdade de Direito da Universidade de Lisboa, 2006.

NABAIS, José Casalta. Responsabilidade civil da administração fiscal. Coimbra: Ed. Coimbra, 2009. p. 730-753.

NEUMANN, Ulfrid. Deontologische und konsequentialistische Argumentationen in recht und moral. Jahrbuch für Recht und Ethik, n. 2, p. 81-94, 1994.

PINHEIRO, Rui. Democracia, poder judicial e responsabilidade dos juízes. COIMBRA. Ministério da Justiça. Responsabilidade civil extracontratual do Estado. Coimbra: Ed. Coimbra, 2002. p. 67-78. Trabalhos preparatórios da reforma.

QUADROS, Fausto de. Intervenção. In: COIMBRA. Ministério da Justiça. Responsabilidade civil extra-contratual do Estado. Coimbra: Ed. Coimbra, 2002. p. 54-65. Trabalhos preparatórios da reforma.

SILVA, José Luís Moreira da. Da responsabilidade civil da administração pública por actos ilícitos. In: QUADROS, Fausto de (Coord.). Responsabilidade civil extracontratual da administração pública. 2. ed. coimbra: almedina, 2004. p. 135-189.

SILVA, Vasco Pereira da. Era uma vez ... o contencioso da responsabilidade civil pública. $C J A$, n. 40, p. 60-69, 2003.

SOUSA, Marcelo Rebelo de; MATOS, André Salgado de. Direito Administrativo Geral. 2. ed. Lisboa: Dom Quixote, 2009. Tomo III: Actividade administrativa.

Submetido em: 20/11/2013 Aprovado em: 23/11/2014

Como citar: MOURA, Bruno. A responsabilidade civil extracontratual do Estado e demais entidades públicas no exercício da função administrativa: uma breve análise do regime português. Scientia Iuris, Londrina, v.18, n.2, p.125-144, dez.2014. DOI:10.5433/21788189.2014v18n2p125. 